\title{
GIPR wt Allele
}

National Cancer Institute

\section{Source}

National Cancer Institute. GIPR wt Allele. NCI Thesaurus. Code C51453.

Human GIPR wild-type allele is located in the vicinity of $19 q 13.3$ and is approximately 14

$\mathrm{kb}$ in length. This allele, which encodes gastric inhibitory polypeptide receptor protein,

plays a role in the regulation of insulin secretion and other facets of the anabolic response. 